Dept. of Biochemistry,

Animal Health Research Institute, El. Mansoura Lab.

\title{
INFLUENCE OF FEEDING ONION WASTE ON SOME BLOOD COMPONENTS AND RUMEN PARAMETERS OF SHEEP
}

(With 6 Tables)

By

\section{S.A. TAWFIK; R.A. EL-RAMADY; H.A. SHALABY and S.S.S. YONIS}

(Received at 23/11/2008)

أثر تغذية مخلفات البصل علي بعض مكونات الام وقياسات الكرش

سبي أحدد توفيق عيل ، رأفت أحمد الرمادى ، حامد عبل المجيا الإمام شلبى ،

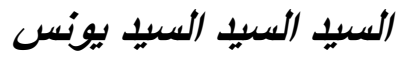

أجريت هذه الدر اسة علي الأغنام بهدف معرفة تأثثر استخدام مخلفات البصل كمصدر

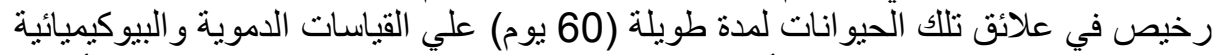

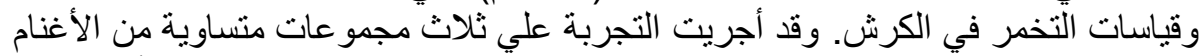

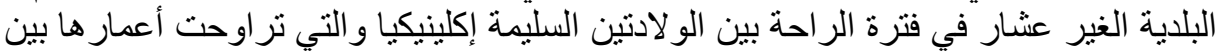

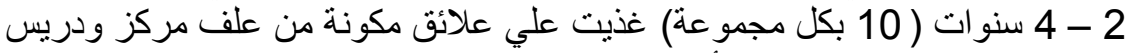

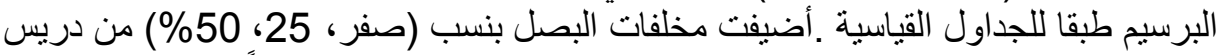

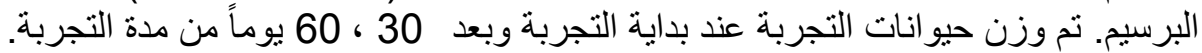

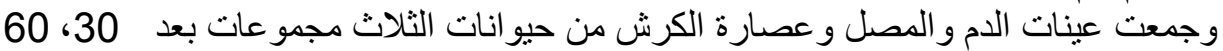

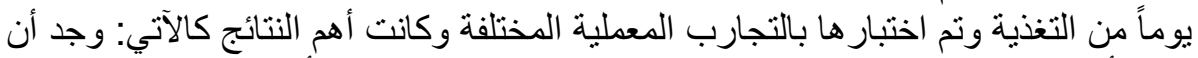

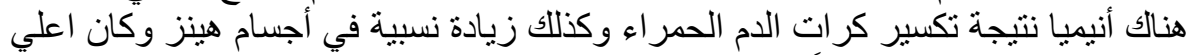

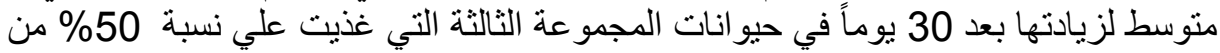

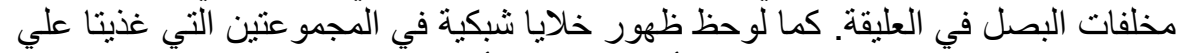

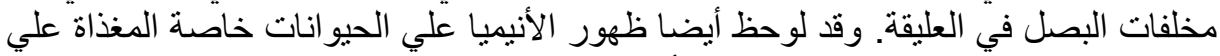

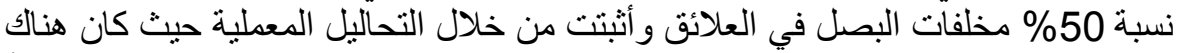

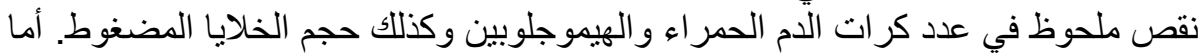

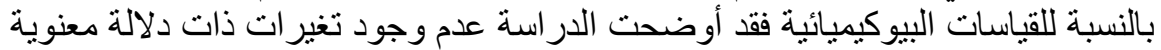

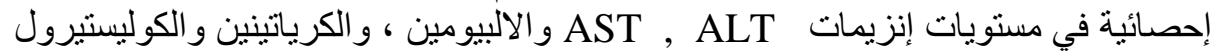

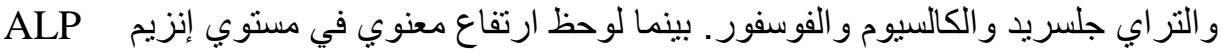

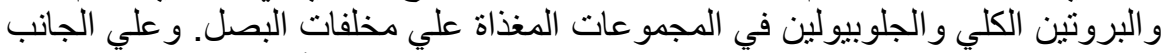

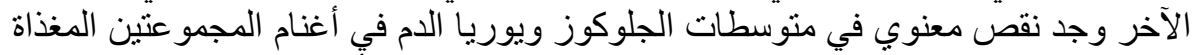

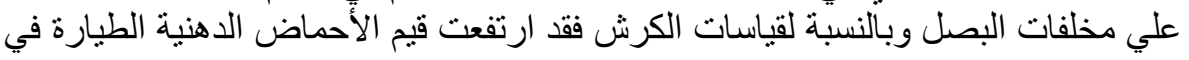




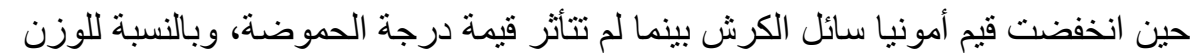

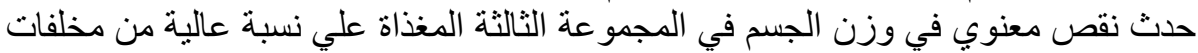

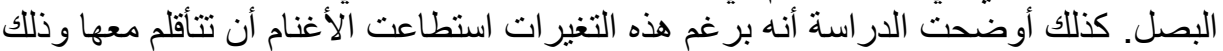

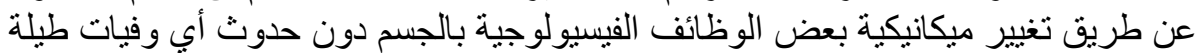

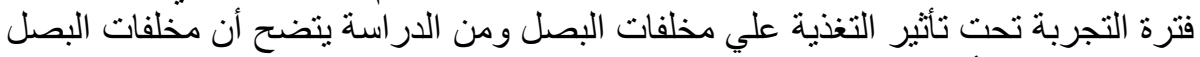
يمكن إضافتها للأعلاف بنسبةلا تزيد عن 25\%

\section{SUMMARY}

The effect of long term (60 days) of onion waste feeding (as economic Source of feed ) on some blood constituents and rumen parameters of 30 non pregnant balady ewes during the interval period was studied at private farm located in Manzala, Dakahlia Governorate. The animals were allocated in 3 equal groups (ten/each) and received (0,25 and 50\%) onion waste on dry matter basis in their ration with supplemental concentrate feed mixture and barseem hay to cover their maintenance nutrient requirement according to NRC (1985). The animals weighed early morning after over night fasting at the beginning and every 30 days post feeding trial. Blood, serum and rumen samples were collected from all animals at 30 and 60 days of feeding trial for laboratory analysis. The results of the present study revealed a picture of anemia which is more evident in sheep fed 50\% onion waste due to intravascular haemolysis. Heinz body was detected in blood of sheep fed onion waste with the highest mean value on 30 days. Also reticulocytes was observed in onion waste fed sheep at 30 and 60 days post feeding. The anemia of sheep fed onion waste had evidences by decreased erythrocyte count, haemoglobin concentration and haematocrite value. No significant changes were recorded in the activities of serum aspartate aminotransferase (AST), alanine aminotransferase (ALT), albumin, creatinine, cholesterol, triglycerides, calcium and phosphorus. In contrast the values of blood urea nitrogen and glucose were significantly decreased while the activity of ALP, serum total protein and globulin were increased with onion waste feeding. The mean values of ruminal TVFAs was higher while ammonia nitrogen concentration were reduced with onion waste feeding when compared with control. The rumen $\mathrm{pH}$ not affected. The body weight decreased with high level onion waste feeding when compared with low level onion waste feeding or control. In spite of these alteration, sheep could adapted their physiological mechanisms under the accumulative onion waste feeding stress and survived without any mortality. 
Key words: Onion waste feeding, onion toxicity, blood analysis, rumen parameters, sheep

\section{INTRODUCTION}

Onions (Allium cepa) are commonly used as an economical source of feed for sheep. The plant has approximately the same nutritional value as barley on a dry matter basis (Lincoln et al., 1992 and Corah et al., 1994). Onions are known to be toxic to many species of animals including cattle, horses, sheep, goats, dogs and cats. Cattle are the most susceptible while sheep and goats are able to tolerate onion in their diet (Parton, 2000). Onions whether cooked, raw or dehydrated contain sulphur compounds that, when chewed are hydrolysed to thiosulfinates which decomposed to a number of disulfides, including dipropenyl disulfide (or n-propyl disulfide) which appears to be the most toxic disulfide (Lincoln et al., 1992 and Selim et al., 1998). Onion poisoning was accompanied by hemolytic anemia, increase in methemoglobin concentration and Heinz body formation which the animal recovered promptly after change of feed (Koger, 1956). Heinz body hemolytic anemia was induced in sheep fed on diet containing cull onions after 22 days of daily consumption of $20 \mathrm{~kg}$ of onions/ewe (Knight et al., 2000).

Literature on using onion waste in sheep feeding and their effect on health status is scarce, therefore, the present study aimed to use onion waste as an economic source of feeding in addition to explore the variations that occurs in some blood components and ruminal parameters of sheep fed onion wastes in two levels.

\section{MATERIALS and METHODS}

\section{(I) Animals:}

The present investigation was carried out on 30 non pregnant balady ewes during interval period aged 2-4 years and weighed on average $62.7 \mathrm{~kg}$. These animals were part of flock reared in private farm located in Manzala at Dakahlia Governorate. All used animals were apparently healthy and free from any internal and external parasites after examination according to the methods described by Soulsby (1986). The feeding trial was carried out during summer months of 2008.

\section{(II) Experimental designs:}

The chosen animals were allocated randomly into 3 equal groups (ten/each) and housed separately in semi-roofed yard. 
Sheep were fed on barseem hay \& concentrate mixture. Onion waste replace $25 \% \& 50 \%$ of barseem hay in groups $2 \& 3$ respectively as shown in Table (1).

Table 1: Composition of the used experimental rations.

\begin{tabular}{|l|c|c|c|}
\hline \multicolumn{1}{|c|}{ Rations and groups } & $\begin{array}{c}\text { Concentrate } \\
\text { feed mixture } \\
(\mathrm{CFM})\end{array}$ & $\begin{array}{c}\text { Barseem } \\
\text { hay }(\mathrm{BH})\end{array}$ & $\begin{array}{c}\text { Onion } \\
\text { waste } \\
(\mathrm{OW})\end{array}$ \\
\hline Control ration $\left(\mathrm{G}_{1}\right)$ & $30 \%$ & $70 \%$ & 0 \\
\hline Low onion waste ration $\left(\mathrm{G}_{2}\right)$ & $30 \%$ & $45 \%$ & $25 \%$ \\
\hline High onion waste ration $\left(\mathrm{G}_{3}\right)$ & $30 \%$ & $20 \%$ & $50 \%$ \\
\hline
\end{tabular}

Feed allowances were calculated to satisfy the maintenance requirements of sheep according to $N R C$ (1985). The CFM consists of $20 \%$ un-decorticted cotton seed meal, $40 \%$ yellow corn, 6\% soybean meal, $25 \%$ wheat bran, $5 \%$ molasses, $2.5 \%$ limestone, $1 \%$ common salt and $0.5 \%$ mineral mixture. The chemical analysis of CFM, BH and OW are shown in Table (2). Water was available all times. The rations were offered twice daily at 9 am and $3 \mathrm{pm}$. All animals were weighed early morning after overnight fasting at the beginning of the experiment, after 30 days post feeding $\&$ at the end of experiment (60days).

Table 2: Chemical composition (\% on DM basis) of feeds and ingredients used in experimental rations

\begin{tabular}{|l|c|c|c|c|c|c|c|}
\hline \multirow{2}{*}{ Item } & \multirow{2}{*}{ DM } & \multicolumn{6}{|c|}{ Chemical composition } \\
\cline { 3 - 8 } & & OM & CF & CP & EE & NEF & ASH \\
\hline $\begin{array}{l}\text { Concentrate feed } \\
\text { mixture (CFM) }\end{array}$ & 91.60 & 94.21 & 15.95 & 15.63 & 2.97 & 59.66 & 5.79 \\
\hline Barseem hay (BH) & 90.03 & 88.23 & 27.85 & 10.97 & 2.40 & 47.01 & 11.77 \\
\hline Onion waste (OW) & 89.4 & 93.6 & 22.1 & 9.7 & 4.9 & 56.9 & 6.4 \\
\hline
\end{tabular}

DM: dry matter OM: organic matter

$\mathrm{CP}$ : crude protein
CF: crude fiber

NFE: nitrogen free extract

\section{(III) Sampling:}
(A) Blood samples: 
Two blood samples were collected from each animal at (30 and 60 days) post feeding trial

(1) Whole blood samples: Five mls of blood were drawn from Jugular vein of each animal into heparinized test tubes. Heinz body in erythrocytes was detected by the use of vital staining with 5\% brilliant green (Selim, 1997). Reticulocytes were detected by vital stain with new methylene blue (Schalm et al., 1986). The concentration of reduced glutathione in the erythrocytes was estimated by the measurement of the 5,5-dithiobis-(2nitrobenzoate) derivative (Beutler et al., 1963). Blood haemoglobin (Hb) was determined by using Sahli's haemoglobinometer according to Schalm et al., (1986). The packed cell volume was determined by using micro- haematocrite method according to Kelly (1984). The total erythrocytic and leucocytic counts were determined using improved haemocytometer according to the method described by Schalm et al., (1986). Mean corpuscular volume $(\mathrm{MCV})$, mean corpuscular haemoglobin $(\mathrm{MCH})$ and mean corpuscular haemoglobin concentration (MCHC) were calculated according to the equation of Wintrobe et al., (1976).

(2) Serum samples: five mls of blood from each animal were drawn into test tube without anticoagulant, left to clot and centrifuged at 3000 r.p.m for 20 minutes, only clear serum were obtained for biochemical analysis. Blood serum aspartate aminotransferase (AST) and alanine aminotransferase (ALT) were measured using an automatic spectrophotometer according to the method described by Reitman and Frankel (1957). Blood serum alkaline phosphatase (ALP) was determined according to Bowers and McComb (1975). Serum total protein was measured according to the method described by Henry and Webster (1964). Serum albumin was determined after the method described by Baure (1982). Serum globulin was calculated mathematically. Serum glucose was estimated after the method of Torlotin (1966). Blood urea nitrogen level was determined according to Patton and Crouch (1977). Serum creatinine level was determined after the method described by Thomas (1992). Serum cholesterol was carried colorimetrically according to the method described by Stein (1986). Triglycerides was estimated according to the method described by Mgtowan et al. (1983). Serum calcium was determined after the method described by Gindler and King, (1972). Serum inorganic phosphorous was 
estimated according to the method described by Morinal and Prox (1973).

\section{(B) Rumen fluid samples:}

Rumen fluid samples were taken using stomach tube (3 hours post-feeding) at 30 and 60 days of the feeding trial. The samples were filtered through 3 layers of gauze and directed for the determination of $\mathrm{pH}$ value using $\mathrm{pH}$ meter, ammonia nitrogen $\left(\mathrm{NH}_{3}-\mathrm{N}\right)$ concentration according to Conway (1957), while the total volatile fatty acids (TVFAs) were measured according to the technique described by Warner (1964).

(C) Faecal samples:

Faecal samples were collected from all animals before the beginning of the feeding trial for detection of any internal parasites according to Soulsby (1986).

(D) Diet samples:

Samples of feeds were analysed according to A.O.A.C. (1995).

(IV) Statistical analysis:

The obtained data were analysed by using a Software Computer Program (Spsswin, 1995).

\section{RESULTS}

\section{(I) Haematological results:}

Sheep fed rations contained 25 and $50 \%$ onion waste on dry matter basis with supplementation by $\mathrm{CFM}$ and $\mathrm{BH}$ for about 60 days showed a picture of anemia as illustrated in table (3). Heinz body was observed at 30 and 60 days post feeding trial in sheep of $\left(\mathrm{G}_{2}\right)$ and $\left(\mathrm{G}_{3}\right)$ but not seen in controls $\left(\mathrm{G}_{1}\right)$ fed only on CFM and BH.

Heinz body varried in appearance from a single large one to several small ones per erythrocyte.

Reticulocytes were noticed in blood of sheep fed $\mathrm{OW}\left(\mathrm{G}_{2}\right.$ and $\left.\mathrm{G}_{3}\right)$ but not noticed in the control $\left(\mathrm{G}_{1}\right)$.

The erythrocyte reduced glutathione concentration (GSH) decreased significantly in sheep fed on high level of onion waste $\left(\mathrm{G}_{3}\right)$ at 30 and 60 days post feeding trial when compared with either control $\left(\mathrm{G}_{3}\right)$ or low level (OW) fed group $\left(\mathrm{G}_{2}\right)$.

Significant reduction in total erythrocytic count associated with significant decreases in the haemoglobin and packed cell volume were noticed at 60 days post feeding trial in blood of sheep fed (OW) either high or low levels

(groups $2 \& 3$ ) when compared with control group $\left(\mathrm{G}_{1}\right)$. 
In contrast, gradual increases in mean corpuscular volume (MCV) and mean corpuscular haemoglobin (MCH) were observed at (30 and 60 days) post feeding trial in sheep of (group 2 and 3) when compared with control $\left(\mathrm{G}_{1}\right)$.

Mean corpuscular haemoglobin concentration (MCHC) had an opposite direction and showed significant decreases in sheep of $\left(\mathrm{G}_{2}\right.$ and $\mathrm{G}_{3}$ ) when compared with control $\left(\mathrm{G}_{1}\right)$, but the differences were significant only after 60 days post feeding trial.

No differences in total leukocytic count were found between sheep fed on (OW) and control.

\section{(II) Biochemical results:}

The results of serum biochemical analysis (Table 4) revealed no significant changes in serum AST and ALT levels between the different groups. While ALP showed significant increases in serum of $\left(\mathrm{G}_{2}\right.$ and $\left.\mathrm{G}_{3}\right)$ fed low and high (OW) at 30 and 60 days post feeding trial when compared with control $\left(\mathrm{G}_{1}\right)$. Significant increases in serum total protein accompanied by increased serum globulin level were noticed in sheep fed high $(\mathrm{OW})$ level $\left(\mathrm{G}_{3}\right)$ at 30 and 60 days post feeding when compared with control $\left(G_{1}\right)$. No significant alterations were recorded for serum albumin, cholesterol, triglycerides, calcium and phosphorus. Significant reduction in serum urea, creatinine and glucose were noticed in High (OW) fed group $\left(\mathrm{G}_{3}\right)$ at 60 days post feeding trial when compared with both control $\left(\mathrm{G}_{1}\right)$ or low (OW) fed group $\left(\mathrm{G}_{2}\right)$.

\section{(III) Ruminal analysis results:}

Table (5) showed that the rumen total volatile fatty acids (TVFA) was significantly increased at 60 days post feeding trial in sheep fed high (OW) level $\left(\mathrm{G}_{3}\right)$ when compared with other groups.

Concerning the rumen ammonia nitrogen concentration, there was a significant reduction in its values in both $(\mathrm{OW})$ fed groups $\left(\mathrm{G}_{2}\right.$ and $\mathrm{G}_{3}$ ) when compared with control. These reduction were noticed at 30 and 60 days post feeding in high level $(\mathrm{OW})$ fed group $\left(\mathrm{G}_{3}\right)$ but only at 60 days post feeding in low level (OW) fed group $\left(\mathrm{G}_{2}\right)$.

No significant changes in rumen $\mathrm{pH}$ between different groups.

\section{IV) Diet analysis results:}

The chemical composition of CFM, BH and OW are shown in Table (2).

Table 3: Effect of onion waste feeding on haematological parameters of sheep at different periods of feeding trials. 
Assiut Vet. Med. J. Vol. 55 No. 120 January 2009

\begin{tabular}{|c|c|c|c|c|}
\hline \multirow{2}{*}{ Parameters } & \multirow{2}{*}{ Periods* } & \multicolumn{3}{|c|}{ Groups } \\
\hline & & G1 & $\mathrm{G} 2$ & G3 \\
\hline \multirow{2}{*}{ Heinz b. count $\%$} & 30 days & $0^{\mathrm{b}}$ & $1.02 \pm 0.06^{\mathrm{a}}$ & $1.54 \pm 0.017^{\mathrm{a}}$ \\
\hline & 60 days & $0^{\mathrm{b}}$ & $1.36 \pm 0.056^{\mathrm{a}}$ & $1.60 \pm 0.16^{\mathrm{a}}$ \\
\hline \multirow{2}{*}{ Reticulocytic count $\%$} & 30 days & $0^{\mathrm{b}}$ & $0.008 \pm 0.002^{\mathrm{a}}$ & $0.02 \pm 4.24 \times 10^{-3 a}$ \\
\hline & 60 days & $0^{\mathrm{b}}$ & $0.098 \pm 0.009^{\mathrm{a}}$ & $0.12 \pm 5.16 \times 10^{-3 a}$ \\
\hline \multirow{2}{*}{$\begin{array}{l}\text { Reduced GL. Conc. } \\
(\mu \mathrm{mol})\end{array}$} & 30 days & $11.09 \pm 0.31^{\mathrm{a}}$ & $10.98 \pm 0.73^{\mathrm{a}}$ & $9.51 \pm 0.014^{\mathrm{b}}$ \\
\hline & 60 days & $11.31 \pm 0.022^{\mathrm{a}}$ & $9.96 \pm 0.73^{\mathrm{ab}}$ & $9.74 \pm 0.016^{\mathrm{b}}$ \\
\hline \multirow{2}{*}{$\mathrm{Hb}$ conc. $\mathrm{g} / \mathrm{dL}$} & 30 days & $11.01 \pm 0.89^{\mathrm{a}}$ & $11.16 \pm 0.77^{\mathrm{a}}$ & $8.65 \pm 0.013^{b}$ \\
\hline & 60 days & $11.44 \pm 0.013^{\mathrm{a}}$ & $10.64 \pm 0.75^{\mathrm{a}}$ & $7.55 \pm 0.21^{\mathrm{c}}$ \\
\hline \multirow{2}{*}{$\mathrm{PCV} \%$} & 30 days & $32.07 \pm 1.38^{\mathrm{a}}$ & $30.24 \pm 0.75^{\mathrm{a}}$ & $23.19 \pm 0.08^{b}$ \\
\hline & 60 days & $31.30 \pm 0.094^{\mathrm{a}}$ & $30.69 \pm 1.48^{\mathrm{a}}$ & $22.26 \pm 0.053^{b}$ \\
\hline \multirow{2}{*}{ RBCs $\times 10^{6}$} & 30 days & $11.78 \pm 0.46^{\mathrm{a}}$ & $11.48 \pm 0.74^{\mathrm{a}}$ & $8.52 \pm 0.38^{\mathrm{b}}$ \\
\hline & 60 days & $12.13 \pm 0.11^{\mathrm{a}}$ & $10.92 \pm 0.735^{\mathrm{a}}$ & $7.47 \pm 0.21^{\mathrm{b}}$ \\
\hline \multirow{2}{*}{$\mathrm{MCV} \%$} & 30 days & $27.22 \pm 0.55^{\mathrm{a}}$ & $29.05 \pm 0.60^{\mathrm{a}}$ & $27.22 \pm 1.1^{\mathrm{a}}$ \\
\hline & 60 days & $25.81 \pm 0.31^{\mathrm{b}}$ & $29.76 \pm 0.93^{\mathrm{a}}$ & $29.8 \pm 0.62^{\mathrm{a}}$ \\
\hline \multirow{2}{*}{$\mathrm{MCH} \%$} & 30 days & $9.34 \pm 0.02^{b}$ & $10.66 \pm 0.002^{\mathrm{a}}$ & $10.1 \pm 0.35^{\mathrm{a}}$ \\
\hline & 60 days & $9.43 \pm 0.097^{b}$ & $10.24 \pm 0.004^{\mathrm{a}}$ & $10.08 \pm 0.093^{\mathrm{a}}$ \\
\hline \multirow{2}{*}{ MCHC \% } & 30 days & $37.45 \pm 0.44^{\mathrm{a}}$ & $36.76 \pm 0.76^{\mathrm{a}}$ & $37.3 \pm 0.13^{\mathrm{a}}$ \\
\hline & 60 days & $36.55 \pm 0.081^{\mathrm{a}}$ & $34.66 \pm 1.16^{\mathrm{a}}$ & $33.9 \pm 0.068^{b}$ \\
\hline \multirow{2}{*}{ T.L.C $\times 10^{3}$} & 30 days & $11.02 \pm 0.89^{\mathrm{a}}$ & $10.47 \pm 0.72^{\mathrm{a}}$ & $10.56 \pm 0.70^{\mathrm{a}}$ \\
\hline & 60 days & $10.17 \pm 0.72^{\mathrm{a}}$ & $10.39 \pm 0.73^{\mathrm{a}}$ & $11.42 \pm 0.70^{\mathrm{a}}$ \\
\hline
\end{tabular}

Means in the same row with different superscripts differ significantly at $(\mathrm{p}<0.05)$.

* Days post feeding

Table 4: Effect of onion waste feeding on some biochemical parameters of sheep at different periods of feeding trials. 
Assiut Vet. Med. J. Vol. 55 No. 120 January 2009

\begin{tabular}{|c|c|c|c|c|}
\hline \multirow{2}{*}{ Parameters } & \multirow{2}{*}{ Periods* } & \multicolumn{3}{|c|}{ Groups } \\
\hline & & G1 & $\mathrm{G} 2$ & G3 \\
\hline \multirow{2}{*}{ AST (IU/L) } & 30 days & $41.85 \pm 2.92^{\mathrm{a}}$ & $40.79 \pm 1.47^{\mathrm{a}}$ & $39.24 \pm 1.03^{\mathrm{a}}$ \\
\hline & 60 days & $39.92 \pm 1.86^{\mathrm{a}}$ & $38.69 \pm 1.48^{\mathrm{a}}$ & $37.19 \pm 2.95^{\mathrm{a}}$ \\
\hline \multirow{2}{*}{ ALT (IU/L) } & 30 days & $23.69 \pm 1.37^{\mathrm{a}}$ & $23.02 \pm 0.74^{\mathrm{a}}$ & $22.39 \pm 2.19^{\mathrm{a}}$ \\
\hline & 60 days & $21.37 \pm 2.25^{\mathrm{a}}$ & $21.84 \pm 0.73^{\mathrm{a}}$ & $20.37 \pm 2.22^{\mathrm{a}}$ \\
\hline \multirow{2}{*}{ ALP (IU/L) } & 30 days & $188.73 \pm 2.11^{\mathrm{c}}$ & $196.23 \pm 2.16^{\mathrm{b}}$ & $198.64 \pm 2.51^{b}$ \\
\hline & 60 days & $193.58 \pm 2.6^{\mathrm{b}}$ & $197.03 \pm 1.46^{\mathrm{b}}$ & $214.6 \pm 2.62^{\mathrm{a}}$ \\
\hline \multirow{2}{*}{ Total protein $(\mathrm{g} / \mathrm{dL})$} & 30 days & $7.03 \pm 0.13^{b}$ & $7.24 \pm 0.76^{\mathrm{b}}$ & $7.54 \pm 0.099^{\mathrm{a}}$ \\
\hline & 60 days & $7.22 \pm 0.31^{b}$ & $7.36 \pm 7.6^{\mathrm{b}}$ & $7.96 \pm 0.33^{\mathrm{a}}$ \\
\hline \multirow{2}{*}{ Albumin (g/dL) } & 30 days & $3.35 \pm 0.094^{\mathrm{a}}$ & $3.29 \pm 0.34^{\mathrm{a}}$ & $3.47 \pm 0.099^{\mathrm{a}}$ \\
\hline & 60 days & $3.41 \pm 0.072^{\mathrm{a}}$ & $3.39 \pm 0.33^{\mathrm{a}}$ & $3.56 \pm 0.16^{\mathrm{a}}$ \\
\hline \multirow{2}{*}{ Globulin (g/dL) } & 30 days & $3.68 \pm 0.068^{b}$ & $3.95 \pm 0.47^{b}$ & $4.05 \pm 0.193^{\mathrm{ab}}$ \\
\hline & 60 days & $3.81 \pm 0.19^{\mathrm{b}}$ & $3.97 \pm 0.42^{b}$ & $4.4 \pm 0.16^{\mathrm{a}}$ \\
\hline \multirow{2}{*}{ Blood urea (mg/dL) } & 30 days & $26.47 \pm 2.21^{\mathrm{a}}$ & $24.4 \pm 0.80^{\mathrm{a}}$ & $21.4 \pm 2.11^{\mathrm{b}}$ \\
\hline & 60 days & $25.24 \pm 1.87^{\mathrm{a}}$ & $25.47 \pm 0.79^{\mathrm{a}}$ & $16.62 \pm 1.40^{\mathrm{c}}$ \\
\hline \multirow{2}{*}{$\begin{array}{l}\text { Serum creatinine } \\
(\mathrm{mg} / \mathrm{dL})\end{array}$} & 30 days & $0.85 \pm 9.19 \times 10^{-3 a}$ & $0.82 \pm 0.09^{\mathrm{a}}$ & $0.79 \pm 0.13^{\mathrm{a}}$ \\
\hline & 60 days & $0.81 \pm 0.12^{\mathrm{a}}$ & $0.79 \pm 0.006^{\mathrm{a}}$ & $0.62 \pm 0.12^{\mathrm{b}}$ \\
\hline \multirow{2}{*}{ Glucose (mg/dL) } & 30 days & $76.83 \pm 2.92^{\mathrm{a}}$ & $73.44 \pm 2.44^{\mathrm{a}}$ & $70.36 \pm 4.37^{\mathrm{b}}$ \\
\hline & 60 days & $72.68 \pm 3.12^{\mathrm{a}}$ & $69.82 \pm 2.51^{\mathrm{a}}$ & $64.67 \pm 3.63^{\mathrm{b}}$ \\
\hline \multirow{2}{*}{ Cholesterol (mg/dL) } & 30 days & $81.27 \pm 2.92^{\mathrm{a}}$ & $80.13 \pm 1.77^{\mathrm{a}}$ & $79.19 \pm 3.18^{\mathrm{a}}$ \\
\hline & 60 days & $83.12 \pm 3.22^{\mathrm{a}}$ & $78.23 \pm 1.06^{\mathrm{a}}$ & $77.22 \pm 2.21^{\mathrm{a}}$ \\
\hline \multirow{2}{*}{ Triglycerides (mg/dL) } & 30 days & $46.44 \pm 0.87^{\mathrm{a}}$ & $45.96 \pm 0.92^{\mathrm{a}}$ & $45.19 \pm 2.28^{a}$ \\
\hline & 60 days & $43.92 \pm 2.32^{\mathrm{a}}$ & $44.88 \pm 1.34^{\mathrm{a}}$ & $44.65 \pm 1.58^{\mathrm{a}}$ \\
\hline \multirow{2}{*}{ Calcium (mg/dL) } & 30 days & $8.98 \pm 0.28^{\mathrm{a}}$ & $8.74 \pm 0.25^{\mathrm{a}}$ & $8.92 \pm 0.33^{\mathrm{a}}$ \\
\hline & 60 days & $8.78 \pm 0.39^{\mathrm{a}}$ & $8.86 \pm 0.24^{\mathrm{a}}$ & $8.83 \pm 0.31^{\mathrm{a}}$ \\
\hline \multirow{2}{*}{$\begin{array}{l}\text { Inorganic phosphorus } \\
(\mathrm{mg} / \mathrm{dL})\end{array}$} & 30 days & $5.54 \pm 0.14^{\mathrm{a}}$ & $5.53 \pm 0.18^{\mathrm{a}}$ & $5.52 \pm 0.090^{\mathrm{a}}$ \\
\hline & 60 days & $5.624 \pm 0.16^{\mathrm{a}}$ & $5.49 \pm 0.21^{\mathrm{a}}$ & $5.48 \pm 0.12^{\mathrm{a}}$ \\
\hline
\end{tabular}

Means in the same row with different superscripts differ significantly at $(\mathrm{p}<0.05)$.

* Days post feeding

Table 5: Effect of onion waste feeding on some ruminal parameters of sheep at different periods of feeding trials. 
Assiut Vet. Med. J. Vol. 55 No. 120 January 2009

\begin{tabular}{|l|c|c|c|c|}
\hline \multirow{2}{*}{ Parameters } & \multirow{2}{*}{ Periods $*$} & \multicolumn{3}{|c|}{ Groups } \\
\cline { 3 - 5 } & & G1 & G2 & G3 \\
\hline \multirow{2}{*}{ TVFAs mmol/L } & 30 days & $88.72 \pm 3.42^{\mathrm{b}}$ & $94.19 \pm 1.41^{\mathrm{ab}}$ & $97.77 \pm 2.28^{\mathrm{a}}$ \\
\cline { 2 - 5 } & 60 days & $89.09 \pm 2.95^{\mathrm{b}}$ & $96.27 \pm 2.12^{\mathrm{ab}}$ & $100.46 \pm 4.52^{\mathrm{a}}$ \\
\hline \multirow{2}{*}{$\begin{array}{l}\text { Ammonia nitrogen } \\
\text { conc. }(\mathrm{g} / \mathrm{dL})\end{array}$} & 30 days & $0.27 \pm 0.008^{\mathrm{a}}$ & $0.26 \pm 0.007^{\mathrm{a}}$ & $0.25 \pm 9.19 \times 10^{-3 \mathrm{~b}}$ \\
\cline { 2 - 5 } & 60 days & $0.27 \pm 3.54 \times 10^{-3 \mathrm{a}}$ & $0.24 \pm 0.007^{\mathrm{b}}$ & $0.23 \pm 2.12 \times 10^{-3 \mathrm{~b}}$ \\
\hline \multirow{2}{*}{ pH } & 30 days & $6.82 \pm 0.16^{\mathrm{a}}$ & $6.96 \pm 0.18^{\mathrm{a}}$ & $6.75 \pm 0.52^{\mathrm{a}}$ \\
\cline { 2 - 5 } & 60 days & $6.86 \pm 0.18^{\mathrm{a}}$ & $6.7 \pm 0.08^{\mathrm{a}}$ & $6.62 \pm 0.49^{\mathrm{a}}$ \\
\hline
\end{tabular}

Means in the same row with different superscripts differ significantly at $(\mathrm{p}<0.05)$.

* Days post feeding.

Table 6: Body weight $(\mathrm{kg})$ of sheep at different periods of experiment.

\begin{tabular}{|c|c|c|c|}
\hline \multirow{2}{*}{ Periods* } & \multicolumn{3}{|c|}{ Groups } \\
\cline { 2 - 4 } & G1 & G2 & G3 \\
\hline 0 time & $61.7 \pm 2.26^{\mathrm{a}}$ & $62.9 \pm 2.06^{\mathrm{a}}$ & $63.5 \pm 2.47^{\mathrm{a}}$ \\
\hline 30 days & $62.4 \pm 1.72^{\mathrm{a}}$ & $60.6 \pm 3.21^{\mathrm{a}}$ & $59.8 \pm 2.68^{\mathrm{ab}}$ \\
\hline 60 days & $63.1 \pm 3.01^{\mathrm{a}}$ & $62.3 \pm 1.98^{\mathrm{a}}$ & $57.2 \pm 3.12^{\mathrm{b}}$ \\
\hline
\end{tabular}

Means in the same row with different superscripts differ significantly at $(\mathrm{p}<0.05)$.

* Days post feeding.

\section{DISCUSSION}

Onion is highly palatable material to sheep and cattle and commonly used as an economic source of feed (Lincoln et al., 1992 and Selim, 1997). Waste parts of onion (leaves, vine, hulls and some parts of bulbs) from food processing plants may be used as alternative food substances for cattle and sheep (El-Feel et al., 1999 and Wolf et al., 2003). The adverse effect resulted from onion waste ingestion are depended on species sensitivity and the amount of ingested onion (Parton, 2000).

In the present investigation, sheep which had eaten waste parts of onions developed Heinz body anemia, these results are in agreement with that obtained by Selim et al. (1998) who reported that feeding of onions to sheep (50 g/kg body weight/day) for 15 days developed more severe Heinz body haemolytic anaemia. Knight et al., (2000) also 
observed the same anemia in pregnant ewes after daily consumption of $20 \mathrm{~kg}$ of onions/ewe for 28 days.

Parton (2000) stated that, the over feeding of onion was known to be toxic to many species including human, cattle, horses, sheep, goats, dogs and cats. Onions contain n-propyl disulfide and S-methyl/and Spropenyl cysteine sulphoxides (SMCO and SPCO) that have a strong haemolytic capability. However, all three disulphide were associated with methaemoglobinaemia and haemolytic anemia with Heinz body formation. The results were further supported by those obtained by Linclon et al. (1992) who found that cattle fed onion for 4 months at different percentages $(5,10,15,20$ or $25 \%)$ on dry matter basis developed anemia after one month associated with Heinz body formation. The results of the present study indicated that sheep fed high or low levels of onion wastes showed increases in the percentage of Heinz bodies. These findings were coincided with those obtained by Hutchison (1977); Franken et al. (1980); Verhoeff et al. (1985); Selim et al. (1998) and Klok (2000).

From stand point of view recognition of injured erythrocytes and demonstration of Heinz bodies in damaged erythrocytes were of value in establishing a diagnosis of toxic haemolytic disease. Heinz bodies are small bubble-like projections which protrude from a red blood cell and can be seen when the cells are stained (Pierce et al., 1972). Moreover, Lincoln et al., (1992) reported that Heinz bodies were detected in RBCs of all cattle fed on onions and the percentage was proportional to the amount of onions consumed. Knight et al. (2000) found packed cell volume and body anemia were reduced by about $22 \%$ on average in ewes fed on onions.

The values of erythrocyte reduced glutathione concentration (GSH) presented in Table (3) showed significant reduction in its values. Furthermore, high negative correlation was observed between Heinz body formation and GSH content in sheep erythrocytes. Such results were in agreement with those reported by Yamato and Maede, (1992); Goto et al. (1993) and Selim et al. (1998). Moreover, Goto et al. (1993) attributed the oxidant defense function of (GSH) in sheep erythrocytes to its important protective role against free radicals. The author added that, without GSH, hydrogen peroxide accumulates and causes oxidation of sulphydryle groups of the globin chain leading to denaturation of haemoglobin and formation of Heinz bodies. Significant increase in reticulocytes allover the experimental period in the blood of (groups $2 \& 3$ ) fed low or high (OW) levels (Table 3). Such result points with 
certainly the present anemia due probably to lysis of erythrocytes and the new and immature forms (reticulocytes) were released into circulations, similar interpretation and results was offered by Van Kampen et al. (1970) and Selim (1997).

Erythrocytic parameters in the present study (erythrocytic count, haemoglobin concentration and haematocrite value) were at the lower limits in sheep groups fed OW when compared with control group (mild anemia).

These results were confirmed by those reported by Hutechison (1977); Linclon et al. (1992) and Selim et al. (1998).

In contrast with the gradual decreases in $\mathrm{Hb}, \mathrm{PCV}$ and $\mathrm{RBCs}$ there was gradual increases in the mean corpuscular haemoglobin $(\mathrm{MCH})$ and in the mean corpuscular volume (MCV) in sheep groups fed (OW). These results agreed with those obtained by Selim (1997).

Concerning the mean values of total leucocytic count in OW fed groups and the control one, the obtained results (Table, 3) revealed no significant changes between the different groups. Similar results were recorded by Franken et al. (1980) and Verhoeff et al. (1985).

The serum biochemical analysis are illustrated in Table (4). It is evident from the obtained results that, there is no significant variances in the enzyme activities of transaminases (AST and ALT), albumin, creatinine, cholesterol, triglycerides, calcium and inorganic phosphorous between the different groups. Nearly similar results were recorded by Selim (1997). Our finding are also supported by the observation of Hothi et al. (1980) who found that calcium and phosphorus levels in the serum of 2 steers given large amount of onion leaves and bulbs not significantly affected.

On the other side, El-Feel et al. (1999) recorded that onion waste tended to decrease plasma cholesterol in Frisian calves. Dokka et al. (1992) mentioned that AST was decreased in the serum of ewes given green onions, while ALT activity increased on day 20 after feeding.

A significant increase in the activity of alkaline phosphatase (ALP) was observed in sheep fed OW $\left(\mathrm{G}_{2}\right.$ and $\left.\mathrm{G}_{3}\right)$ when compared with control $\left(\mathrm{G}_{1}\right)$. Similar finding was recorded by Lincoln et al. (1992).

Serum total protein revealed increases in its values in sheep fed OW $\left(\mathrm{G}_{2}\right.$ and $\left.\mathrm{G}_{3}\right)$ when compared with control $\left(\mathrm{G}_{1}\right)$ but the differences were significant only between high level (OW) fed group and the control at 30 and 60 days of feeding. These finding are supported by the observation of El-Feel et al. (1999) who recorded that onion waste 
increase $(\mathrm{P}<0.05)$ the concentration of plasma total protein in Frisian calves.

Serum urea nitrogen showed significant decreases in its values in sheep fed high level of OW $\left(\mathrm{G}_{3}\right)$ when compared with the other groups. These results were confirmed by those reported by Kirk and Bulgin (1979) who found marked decrease in blood urea nitrogen in the onion fed sheep.

Serum glucose levels were significantly decreased at 30 and 60 days after $\mathrm{OW}$ feeding to sheep of $\mathrm{G}_{3}$ and $\mathrm{G}_{2}$ respectively. The lowered glucose levels reflected negative energy balance at that periods.

Rumen parameters are presented in Table (5). The TVFAs concentration were increased significantly in the rumen of sheep fed high level OW $\left(\mathrm{G}_{3}\right)$ compared with the other two groups. The highest value of TVFAs $(\mathrm{mmol} / \mathrm{L})$ was recorded with $\mathrm{G}_{3}(100.46 \pm 4.518)$ at 60 days post feeding followed by $(97.77 \pm 2.28)$ at 30 days post feeding for the same group while the lowest value $(89.09 \pm 2.948)$ recorded with the control. This may be attributed to the regulatory action of onion waste on rumen protozoa and other microorganisms which gave high level of VFAs. The results herein agree with those recorded by Selim (1997). Ammonia nitrogen concentration had an opposite direction and revealed decreases in its values in both $\mathrm{OW}$ fed groups $\left(\mathrm{G}_{2}\right.$ and $\left.\mathrm{G}_{3}\right)$ when compared with control. The differences were significant only at 60 days for $\mathrm{G}_{2}$. But at 30 and 60 days for $\mathrm{G}_{3}$. These results were in agreement with those recorded by Selim et al. (1998) who stated that over feeding of onions to sheep increased TVFAs and decreased ammonia nitrogen concentration representing a picture of indigestion.

The results also indicated that there is no significant differences in the rumen $\mathrm{pH}$ among the sheep of the three groups. Similar to those obtained by Fredrickson et al. (1995) and Selim (1997).

On studying the effect of OW feeding on body weight the results (Table 6) indicated that body weight decreased significantly with high level OW feeding $\left(\mathrm{G}_{3}\right)$ when compared with either low level OW feeding $\left(\mathrm{G}_{2}\right)$ or control $\left(\mathrm{G}_{1}\right)$. The decreased body weight in the animal of the third group may be attributed to the anemic condition and indigestion affected these animals under stress of OW feeding.

\section{REFERENCES}

A.O.A.C. (1995): Official Methods of Analysis, $16^{\text {th }}$ Ed., Association of Analytical Chemists, Washington, D.C., USA. 
Baure, J.D. (1982): Colorimetric determination of albumin. Clinical Laboratory Methods, $9^{\text {th }}$ Ed. 495:1121.

Beutler, E.; Duron, O. and Kelly, B.M. (1963): Improved method for the determination of blood glutathione: J. Lab. Clin. Med., 61: 882-888.

Bowers, G.N. and McComb, R.B. (1975): Measurement of the total alkaline phosphatase activating in human serum. Clinical Chemistry 21: 1988-1995.

Conway, F. (1957): Modification analysis and volumetric errors. Rev. Ed. Lockwood, London.

Corah, T.J.; Cannon, J.E.; Levalley, S.B.; Morgan, J.B.; McBride T.; Eisenach, M.; Tatum J.D. and Smith G.C. (1994): Effects of feeding cull onion and carrots on growth rate carcass traits and meat palatability attributes in lambs. Sheep and Goat Research J., 10 (2): 141-145.

Dokka, A.A.; Sadiek, A.H. and Amer, A.A. (1992): Comparison of transaminases activity in both rumen fluid and blood sera of sheep fed different field stubbles. Assiut Vet. Med. J., 54: 148153.

El-Feel, F.M.R.; El-Ghani, A.A.A.; El-Barody, M.A.A. and Fahmy, S.T.M. (1999): Effect of feeding onion wastes and virginiamycin on growth performance, rumen activity, blood and immunology parameters in growth Friesian and buffalo calves. Alexandria Journal of Agricultural Research. 44 (1): 116.

Franken, P.; Beukelen, P. Van and Blok, G. (1980): Onions not a horse feed. Tijdschrift-voor- Diergeneeskude. 105 (13): 529-534.

Fredrickson, E.L.; Estell, R.E.; Havstad, K.M.; Shupe, W.L. and Marray L.W. (1995): Potential toxicity and feed value of onions for sheep. Livestock Production Science, 42 (1): 45-54.

Gindler, E.M. and King, J.D. (1972): Rapid colorimetric determination of calcium in biological fluids with methyl thymol blue. Amer. J. Cli. Path., 58: 376.382.

Goto, I.; Agar, N.S. and Meade, Y. (1993): Relation between reduced glutathione content and Heinz body formation in sheep erythrocytes. Am. J. Vet. Red. 622-626.

Henry, R. and Webster, J. (1964): Clinical Chem. $7^{\text {th }}$ Ed. by Harper and Publishers, New York, p. 181.

Hothi, D.S.; Arneja, J.S. and Chawia, J.S. (1980): Onion (Allium cepa) poising in bullocks. Indian Vet. J., 57 (8): 690-692. 
Hutchison, T.W.S. (1977): Onions as a source of Heinz body anaemia in cattle. Canadian Vet. J. 18 (12): 358-360.

Kelly, W.R. (1984): Veterinary Clinical Diagnosis $3^{\text {rd }}$ Ed. Printed in Great Britain by William Claws Limited, Beccles and London.

Kirk, J.H and Bulgih, W.S. (1979): Effects of feeding cull domestic onions (Allium cepa) to sheep. Am. J. Vet. Res., 397-399.

Knight, A.P.; Lassen, D.; McBride, T.; Marsh, D.; Kimberling, C.; Delgado, M.G. and Gould, D. (2000): Adaptation of pregnant ewes to an exclusive onion diet. Veterinary and Human Toxicology. 42 (1): 1-4.

Koger, L.M. (1956): Onion poisoning in cattle. J.A.V.M.A., 129: 75.

Kolk, J.H. Van-der (2000): Onion poisoning in a herd of dairy cattle. Vet. Rec., 147 (18): 517-518.

Lincoln, S.D.; Howell, M.E.; Combs, J.J. and Hinman, D.D. (1992): Hematologic effect and feeding performance in cattle fed cull domestic onions (Allium cepa). J. A. V. M. A. $1090-1094$.

Mgtowan, M.W.; Artiss, I.D.; Standbergh, D.R. and Zark, B. (1983): A peroxide-copuled method for colorimetric determination of serum triglycerides. Clin. Chem., 29: 538.

Morinal, L. and Prox, J. (1973): New rappid procedure for serum phosphorus using $\mathrm{O}$. phenylen diamine as reluctant. Chin. Chem. Acta. 46: 113-117.

NRC (1985): Nutrient requirement of domestic animals. Nutrient requirement of sheep. National Research Council, Washington.

Parton, K. (2000): Onion toxicity in farmed animals. New Zealand Veterinary Journal, 48 (3): 89-89.

Patton, C.J. and Crouch, S.R. (1977): Enzymatic colorimetric method for determination of urea. Anal. Chem., 49: 464-469.

Pierce, K.R.; Joyce, J.R.; England, R.B. and Jones, L.P. (1972): Acute haemolytic anaemia caused by wild onion poising in horses. J. of Amer. Vet. Med. Asso., 160 (3): 323 - 327.

Reitman, S. and Frankel, S. (1957): Determination of AST and ALT. Amer. J. Clin. Path., 28:56.

Schalm, O.W.; Jain, N.C. and Carroll, E.J. (1986): In veterinary hematology, $4^{\text {th }}$ Ed., Philadelphia, Lea \& Febiger, 95-97.

Selim, H.M. (1997): Studies on rumen ciliate protozoa and the effect of over feeding of onion on blood constituents and rumen microbial activity in sheep. Ph.D. Thesis, Faculty of Vet. Med., Zagazig Univ. 
Selim, H.M.; Yamato, O.; Imai, S.; Miyagawa, E.; Eiryu, O. and Maede, Y. (1998): Effects of feeding onions (Allium cepa) on Blood constituents and rumen microbial activity in sheep. Zag. Vet. J., 126 (2): 50-55.

Soulsby, E.J.L. (1986): Helminths Arthropodies and Protozoa of Domesticated Animals. $1^{\text {st }}$ Ed. Bailliere, Tindell, London.

Spsswin (1995): Statistical Program Under Windows, U.S.A.

Stein, E.A. (1986): In Text Book of Clinical Chemistry. Saunders, Philadelphia. Pp. 879-886.

Thomas, L. (1992): Lobar and diagnose, $4^{\text {th }}$ Edition, Medizinische ver Lagsqeoell schaft, Warburg.

Torlotin, J.C. (1966): Chemical determination of blood serum glucose. Ann. Clin. Biochem., 24: 173.

Van Kampen, K.R.; James, L.F. and Johnson, A.E. (1970): Haemolytic anemia in sheep fed wild onion (Allium validum). J.A.V.M.A., 328-332.

Verhoeff, J.; Hajer, R. and Ingh, T.S.G.A.M. Van-der (1985): Onion poisoning of young cattle. Vet. Rec., 117 (19): 497-498.

Warner, A.C.T. (1964): Production of volatile fatty acids in the rumen methods of measurement. Nutr. Abst. Rev., 34: 339.

Wintrobe, N.M.; Richlee, G.; Boogs, D.R.; Brithell, T.C.; Athenus, J.W. and Forester, J. (1976): Clinical haematology $7^{\text {th }}$ Ed. Indian Ed, K.M. Varghese Company Bombay.

Wolf, P.; Blanke H.J.; Wohlsein, P.; Kamphues, J. and Stober, M. (2003): Animal nutrition for veterinarians actual cases: tulip onions with leaves, an unusual and high risk plant in ruminant feeding. Deutsche - Tierarztliche - Wochenschrift, 110 (7): 302-305.

Yamato, O. and Maede, Y. (1992): Susceptibility to onion induced hemolysis in dog with hereditary high erythrocyte reduced glutathione and potassium concentrations. Am. J. Vet. Res., 134-137. 